\title{
Morphometry of the reproductive system of the predator Podisus nigrispinus (Dallas, 1851) (Hemiptera, Pentatomidae) when submitted to different temperatures
}

\author{
Ítala Tainy Barreto Francisco dos Santos ${ }^{1^{*}}$ (D) Heloisa Safira Santos Pinheiro' ${ }^{1}$ (D) \\ Júlio César Melo Poderoso ${ }^{2}$ (D) Vancleber Batista dos Santos ${ }^{1}$ (D) Thiago Xavier Chagas ${ }^{1}$ (D) \\ Genésio Tâmara Ribeiro' ${ }^{1}$ (1)
}

${ }^{1}$ Programa de Pós-graduação em Agricultura e Biodiversidade, Universidade Federal de Sergipe (UFS), 49100-000, São Cristóvão, SE, Brasil. E-mail: itala.ufs@hotmail.com. *Corresponding author.

${ }^{2}$ Diretor de Controle Ambiental de Rosário do Catete, Secretaria do Meio Ambiente e Desenvolvimento Rural, Rosário do Catete, SE, Brasil.

ABSTRACT: In order to manipulate the mass rearing of natural enemies, temperature variations can be used. The effects are widely studied for their survival and developmental duration; however, there is little information about their reproductive system in the literature. Therefore, the purpose of this study was to evaluate the effects of different temperatures on the reproductive system of the predator Podisus nigrispinus (Dallas, 1851) (Hemiptera: Pentatomidae). The predator was kept at temperature conditions of 17, 21, 25, and $29{ }^{\circ} \mathrm{C}$ until reaching 15 days of age, the adult stage. The insects were then killed, measured for both weight and size, dissected, and then evaluated for the following parameters: length of the most developed ovariole; number of ovarioles per ovary; number of oocytes per the more developed ovarioles; number of oocytes per P. nigrispinus female; and the total area of the testicles was measured in the male insects. Results showed that as the temperature increased, the parameters were positively affected. These temperature variations can be used to manipulate the mass rearing of P. nigrispinus under controlled conditions.

Key words: pentatomidae, predator, natural enemies, mass rearing, biological control.

Morfometria do aparelho reprodutor de Podisus nigrispinus (Dallas, 1851)

(Hemiptera, Pentatomidae) quando submetidos a diferentes temperaturas

RESUMO: As variações de temperatura podem ser utilizadas para manipular a criação massal de inimigos naturais e seus efeitos são amplamente estudados para a sobrevivência e duração de desenvolvimento, porém, existem poucas informações sobre o sistema reprodutivo na literatura. Por isso, o objetivo desse trabalho foi avaliar os efeitos de diferentes temperaturas sobre o aparelho reprodutivo do predador Podisus nigrispinus (Dallas, 1851) (Hemiptera: Pentatomidae). O predador foi mantido nas temperaturas de 17, 21,25 e $29{ }^{\circ} \mathrm{C}$ até atingir 15 dias de idade na fase adulta. Esses insetos foram mortos, medido o peso e tamanho, dissecados e avaliados nos seguintes parâmetros: comprimento do ovariolo mais desenvolvido; número de ovariolo por ovário; números de ovócitos por ovariolo mais desenvolvidos; número de ovócitos por fêmea; e, nos machos, área total do testículo. Os resultados evidenciaram que a medida que aumenta a temperatura os parâmetros foram afetados positivamente. Essas variações de temperatura podem ser utilizadas para manipular a criação massal de P. nigrispinus em condições controladas.

Palavras-chave: pentatomidae, predador, inimigos naturais, criação massal, controle biológico.

\section{INTRODUCTION}

Podisus nigrispinus (Dallas, 1851) (Hemiptera: Pentatomidae) is a species of stinkbug that is common in Neotropical regions and due to its generalist eating behavior (LUNDGREN, 2011), it is regarded as an important biological pest control agent in various agricultural and forest crops (MEDEIROS et al., 2003; VACARI et al., 2014; ZANUNCIO et al.,
1994), such as soy, (FERREIRA et al., 2008), cotton (MEDEIROS et al., 2000), tomato (TORRES et al., 2002), and eucalyptus (ZANUNCIO et al., 2002).

This predator has been massively reared in the laboratory and then released into cultivated areas where pest-insect outbreaks occurs (BOTTEGA et al., 2014; ZANUNCIO et al., 2002). Once the balance is established in the field, companies that maintain these particular mass rearing extend the developmental 
cycle of the insects. This is mostly because maintaining a mass-rearing at high population levels throughout the year requires a high economical cost (NEVES et al., 2010).

This increment of the developmental cycle can be accomplished by exposing the natural enemy to low temperatures, since it is known that temperature is the main factor responsible for the insect's functions, such as survival, development, and reproduction (REBAUDO \& RABHI, 2018). The influence of temperature on $P$. nigrispinus is well understood on the adult's survival, developmental time, and longevity parameters (COSTA et al., 2016; MEDEIROS et al., 2003; SANTOS et al., 2018). However, there is a lack of studies about the reproductive system of this predator.

For this reason, it is important to understand the influence of temperature on the reproductive system of insects, aiming to the improve mass rearing (MEDEIROS et al., 2003), since unfavorable conditions may cause morphological variations in the reproductive organ of the predator $P$. nigrispinus(LEMOS et al., 2005a). Thus, the objective of this study was to evaluate the effects of different temperatures on the reproductive system of the predator P. nigrispinus.

\section{MATERIALS AND METHODS}

\section{Insects}

The tests were carried out at the Forest Entomology Laboratory in the Forestry Sciences Department located in the Federal University of Sergipe, Sergipe, Brazil. In the laboratory, the insects used were reared in screened cages of $60 \times 40 \times 40 \mathrm{~cm}$ (adults) and Petri dishes $(9.0 \mathrm{~cm}$ diameter $\times 1.5 \mathrm{~cm}$ $\mathrm{H}$ ) (nymphs) under the conditions of $25 \pm 0.5^{\circ} \mathrm{C}, 60$ $\pm 9.5 \% \mathrm{RH}$, and a 12:12 h (L:D) photoperiod.

About 200 adults of the predatory stinkbug $P$. nigrispinus were kept in cages and fed with the pupae of its alternative prey Tenebrio molitor (Linnaeus) (Coleoptera: Tenebrionidae) (previously obtained from a mass rearing in the same laboratory). Water was provided through moistened cotton balls, which were deposited on the top screen of the cage. Eggs deposited by the females in the cages were collected daily with aid of a cotton ball, and then about 40 eggs were transferred to the Petri dishes $(9.0 \mathrm{~cm}$ diameter $\times 1.5 \mathrm{~cm} \mathrm{H}$ ) containing a moistened cotton plug with distilled water. After hatching, the nymphs remained in these cages and were fed with $T$. molitor pupae until the adult stage, when they were transferred to another cage $(60 \mathrm{~cm} \times 40 \mathrm{~cm} \times 40 \mathrm{~cm})$ for mating.
Morphometry of the ovaries and the testicles of the P. nigrispinus adults that were submitted to different temperatures

The eggs of up to 24 hours were collected and submitted to the treatments, which consisted of four temperatures, $17,21,25$, and $29{ }^{\circ} \mathrm{C} \pm 0.5{ }^{\circ} \mathrm{C}$. Each treatment was composed of ten replicates, and in each replicate, one egg was deposited in the Petri dishes containing a moistened cotton ball with distilled water on the lid. After hatching, the nymphs were kept in the same Petri dishes, where the water supply was provided daily, as well as with the feeding of T. molitor pupae.

Once they reached the adult stage, the stinkbugs were dissected for further analysis of the reproductive system. Females, who were obtained from the nymphs, were exposed to the temperatures as cited above. They were killed at 15 days of age in the adult stage by the usage of ethyl acetate and then dissected under a binocular stereoscopic microscope. This 15-day-age was used because the maturation peak of the eggs occurs between 8 and 18 days old (MEDEIROS et al., 2000).

Before the dissection, the weight, the width, and the length of the females were measured with an analytical balance and a Vernier caliper. The ovaries were photographed and evaluated for the following parameters: (a) the length of the most developed ovariole; (b) the number of ovarioles per ovary; (c) the oocyte numbers per the more developed ovariole; and (d) the number of oocytes perP. nigrispinus female.

For the males, the 15-day-old P. nigrispinus adults were killed, measured, and dissected the same way as mentioned for the females. The evaluated parameter was the total area of the insect's testicles. All of the parameters were quantified through ImagePro Plus version 4.5.1.29 (Media Cybernetics, Inc) (LEMOS et al., 2005b).

\section{Statistical analysis}

All of the parameters were submitted to an analysis of variance (one-way ANOVA) and then to regression analysis, being the models selected, according to the significance of the regression coefficients $(t, P<0.05)$ and the coefficient of determination $\left(R^{2}\right)$. The statistical analyses were performed by the usage of SISVAR 5.0 software (FERREIRA, 2014).

\section{RESULTS}

When kept under the temperatures of $17,21,25$, and $29^{\circ} \mathrm{C}$, the predator P. nigrispinus 
presented variations over the evaluated parameters and, in general, as the temperature increased, the parameters were positively affected (Table 1 and Table 2; Figure 1 and Figure 2).

The weight of the females who underwent the treatments was enhanced with an increase of temperature and this was represented by an increasing linear equation. The same situation was observed for the width and the length of the females and in the length of the most developed ovariole (Table 1).

When regarding the number of ovarioles per ovary, the study observed seven at all of the temperatures, with no significant differences between the treatments. The number of oocytes per ovariole and the number of oocytes per female were enhanced with an increase of temperature, and it was evidenced that the amount of oocyte at $29^{\circ} \mathrm{C}$ was approximately twice as high as it was at $17^{\circ} \mathrm{C}$ (Table 1).

In the $P$. nigrispinus males, the lowest weight was observed at the lowest temperature, but the weight was enhanced as the temperature increased. Conversely, the width of the male body was higher at temperatures of $17^{\circ} \mathrm{C}$ and $29^{\circ} \mathrm{C}$ than it was at temperatures of $21{ }^{\circ} \mathrm{C}$ and $25^{\circ} \mathrm{C}$ (Table 2).

The length of the male body and its testicular area were also enhanced with the temperature increase. However, it was observed that the testicular area at $17^{\circ} \mathrm{C}$ was much smaller when compared to both body length and width of the insect, so in this condition, the testicles were considered immature (Table 2).

\section{DISCUSSION}

In this study, the $P$. nigrispinus insects that were kept under different temperature conditions and fed with $T$. molitor presented weights of between 51.78 to $62.40 \mathrm{mg}$ and 36.75 to $44.15 \mathrm{mg}$ for the females and the males, respectively. Normally, under ambient temperature conditions, the females had a higher body mass (45 to $140 \mathrm{mg}$ ) than did the males (35 to $100 \mathrm{mg}$ ) (TORRES et al. 2006). The weight variations between same-sex individuals were attributed to the nutritional quality of their prey (LEMOS et al., 2003; VACARI et al., 2007). However, the weight variations in the same-sex insects within the studied temperatures were related to the prey's T. molitor consumption stimulus, and not to its nutritional quality.

The temperature was an environmental factor that affected the food consumption rate, as well as the digestibility and the conversion efficiency of the food by the insects (RAHMATHULLA \& SURESH, 2012). This was observed in the insects that were submitted to $17{ }^{\circ} \mathrm{C}$ and that presented a low consumption of the $T$. molitor prey, resulting in poor performance of the reproductive system. This

Table 1 - Morphometric parameters of the body and the reproductive system of the $P$. nigrispinus females when submitted to different temperatures $\left(17,21,25\right.$, and $\left.29^{\circ} \mathrm{C} \pm 0.2{ }^{\circ} \mathrm{C}\right)$.

\begin{tabular}{lcr}
\hline Parameters & & \\
\hline & & \\
\hline
\end{tabular}

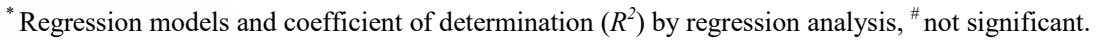


Table 2 - Morphometric parameters of the body and the reproductive system of the $P$. nigrispinus males when submitted to different temperatures $\left(17,21,25\right.$, and $\left.29^{\circ} \mathrm{C} \pm 0.2^{\circ} \mathrm{C}\right)$.

\begin{tabular}{|c|c|c|c|c|}
\hline \multirow{2}{*}{$\begin{array}{l}\text { Parameters } \\
\text { Males }\end{array}$} & \multicolumn{4}{|c|}{ 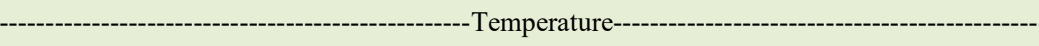 } \\
\hline & $17^{\circ} \mathrm{C}$ & $21^{\circ} \mathrm{C}$ & $25^{\circ} \mathrm{C}$ & $29^{\circ} \mathrm{C}$ \\
\hline Weight (mg) & $35.75 \pm 4.76$ & $39.96 \pm 3.30$ & $41.06 \pm 2.87$ & $44.79 \pm 3.33$ \\
\hline \multicolumn{5}{|c|}{ - } \\
\hline Male body width $(\mathrm{cm})$ & $0.46 \pm 0.03$ & $0.44 \pm 0.01$ & $0.43 \pm 0.02$ & $0.49 \pm 0.02$ \\
\hline \multicolumn{5}{|c|}{ - ${ }^{*} Y=0.0013 x^{2}-0.0555 x+1.0453 ; R^{2}=0.91$} \\
\hline Male body length (cm) & $0.82 \pm 0.03$ & $0.86 \pm 0,02$ & $0.88 \pm 0,03$ & $0.90 \pm 0.00$ \\
\hline \multicolumn{5}{|c|}{ - ${ }^{*} Y=0.0065 x+0.7139 ; R^{2}=0.98$} \\
\hline Total area of the testicles $\left(\mathrm{mm}^{2}\right)$ & $0.33 \pm 0.05$ & $0.73 \pm 0.11$ & $0.77 \pm 0.12$ & $0.97 \pm 0.17$ \\
\hline
\end{tabular}

${ }^{*}$ Regression models and coefficient of determination $\left(R^{2}\right)$ by regression analysis.

was because the energy resource that is acquired in the immature phase through nutrition, subsidizes the growth and the reproduction of the insects; this process contributes to vitello genesis and the maturation of the eggs (CHAPMAN, 2013; ATTARDO et al., 2005).

At the evaluated temperatures, the insects with a higher body mass presented a greater length and width. This was because the weight was a critical factor in determining the body size (DAVIDOWITZ et al., 2003); consequently, the larger individuals tended to have a higher body mass, with longevity and fecundity (WANG et al., 2009).

The length of $P$. nigrispinus varied from 0.96 to $1.03 \mathrm{~cm}$ and 0.82 to $0.90 \mathrm{~cm}$ for the females and the males, respectively. These results are common and are in agreement with the ones reported by TORRES et al.(2006), where in adulthood, the predator had a size ranging from 1.0 to $1.2 \mathrm{~cm}$ (females) and 0.85 to $1.0 \mathrm{~cm}$ (males).
One of the parameters of the reproductive system evaluated was the number of ovarioles per ovary, which regardless of the temperature used, seven ovarioles were reported. This result revealed that the temperature did not affect the number of ovarioles since it remained similar to those reported when the predator P. nigrispinus was fed with different prey (LEMOS et al., 2005a) or when the ovary development in the mated and virgin females was compared (SOARES et al., 2011).

The ideal temperature for $P$. nigrispinus and its development was $25^{\circ} \mathrm{C}$. At conditions above $33{ }^{\circ} \mathrm{C}$, the predator was negatively affected presenting low hatching of eggs $(26 \%)$ (MEDEIROS et al., 2003). In the evaluated morphometric parameters, the temperature of $25{ }^{\circ} \mathrm{C}$ was favorable to the predator $P$. nigrispinus, however, at $29{ }^{\circ} \mathrm{C}$, the evaluated parameters were higher, so it was possible to keep the insects under these conditions, without harming the reproductive potential of the species.

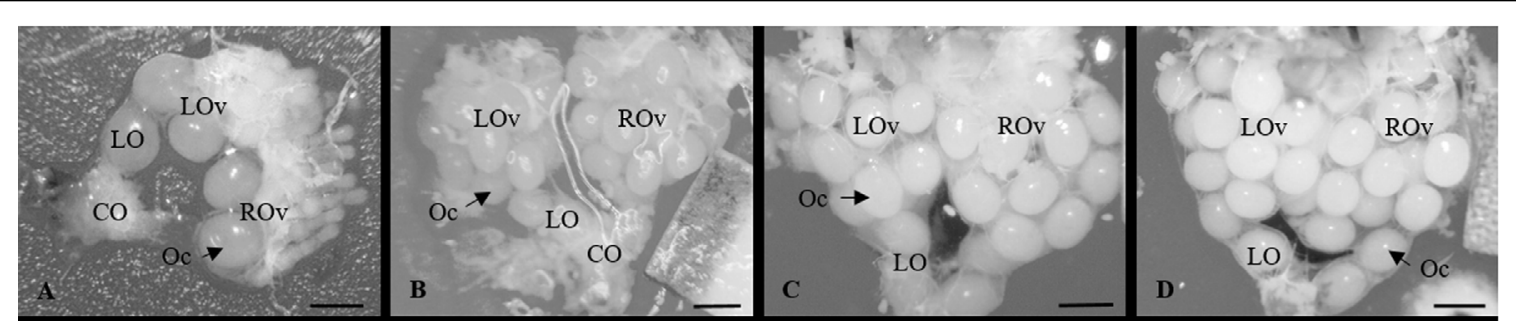

Figure 1 - Reproductive system of the P. nigrispinus females when submitted to different temperatures: $17^{\circ} \mathrm{C}(\mathrm{A}) ; 21{ }^{\circ} \mathrm{C}(\mathrm{B}) ; 25^{\circ} \mathrm{C}$ (C); and $29^{\circ} \mathrm{C}$ (D) . Common oviduct (CO); Oocyte (Oc); Lateral oviduct (LO); Left ovary (LOv); Right ovary (ROv). Bars $=0.10 \mathrm{~mm}$ 


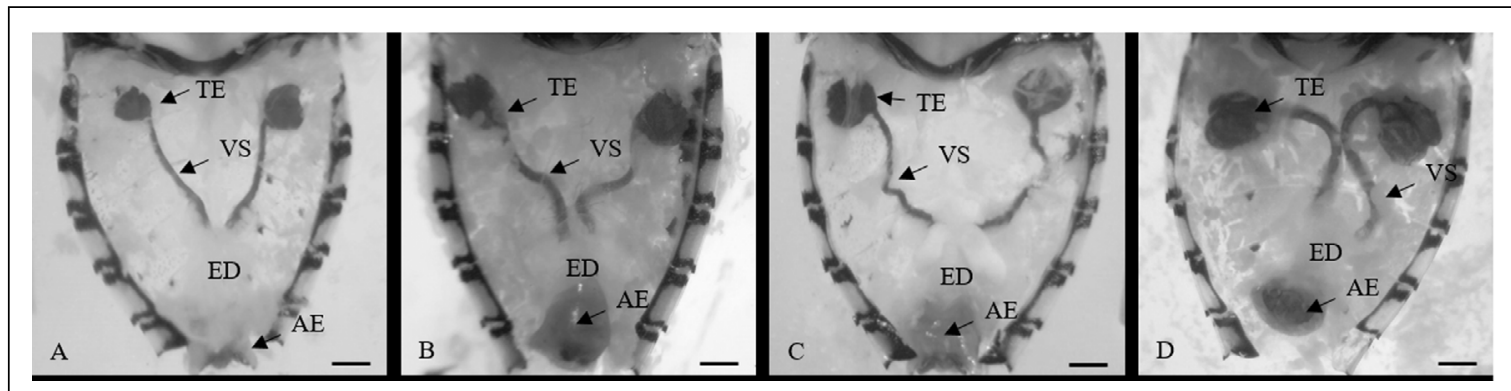

Figure 2 - Reproductive system of the P. nigrispinus males when submitted to different temperatures: $17^{\circ} \mathrm{C}(\mathrm{A}) ; 21^{\circ} \mathrm{C}(\mathrm{B}) ; 25^{\circ} \mathrm{C}$ (C); and $29^{\circ} \mathrm{C}$ (D) . Testicle (TE); Vas deferens (VS); Ejaculatory duct (ED); Aedeagus (AE). Bars $=0.20 \mathrm{~mm}$.

The temperature influenced the speed of the insect's development, being greater under the higher conditions (BUSATO et al., 2004). Therefore, the increase in temperature led to the fast development of the ovarioles, resulting in a larger amount of oocytes per ovariole and per ovarian. In the insects that were maintained at a temperature of $17{ }^{\circ} \mathrm{C}$, besides presenting lower weights and body sizes, they presented a shorter ovariole length, oocyte number, and a smaller testis area. The same occurred for Pentatomidae Piezodorus guildinii (Hemiptera) when exposed to temperature variations, where the body size was related to the reproductive performance (the size of the ovaries and the testicles) (ZERBINO et al., 2014).

The temperature of $17^{\circ} \mathrm{C}$ also affected the reproductive system of the males through a testicle reduction, making it immature. When males of the $P$. guildinii was submitted to temperature variations of $20{ }^{\circ} \mathrm{C}$ and $25{ }^{\circ} \mathrm{C}$, and 10 and 14 hours photophase, respectively, also presented smaller testicles at the lower temperature. They were then considered immature as well (ZERBINO et al., 2014).

Therefore, it can be inferred that temperature plays a crucial role in the life of these insects, which can then negatively or positively affect their development, survival and reproduction (SILVA, 2004; MEDEIROS et al., 2004; REBAUDO $\&$ RABHI, 2018). These insects can only reach adulthood and reproduce within a temperature gradient, with an optimal temperature. Nevertheless, negative effects can be expected when the insects are subjected to temperatures that are close to the minimum and maximum limits that they can withstand (HADDAD et al., 1999; CARRANOMOREIRA, 2014). Thus, the data obtained in this research has allowed for an understanding of the effects of different temperatures on the reproductive system of the $P$. nigrispinus aiming to improve mass rearing and extract the maximum of its potential as a predator. In addition, when necessary, it is possible to previously adapt the insects reared in mass to the climate and conditions of the place where they will be released.

\section{CONCLUSION}

The temperature variations can be used to manipulate the mass rearing of $P$. nigrispinus. Reinforcing that within the thermal limit, the temperature of $17{ }^{\circ} \mathrm{C}$ reduce the size of the insect's body and its reproductive system, besides reducing the number of oocytes produced by the females, as well as causing immature testicles. However, the temperature of $29{ }^{\circ} \mathrm{C}$ increase the insect's development and this was equally favorable to the predator, as far as the recommended temperature in the literature $\left(25^{\circ} \mathrm{C}\right)$.

\section{ACKNOWLEDGSMENTS}

This study was financed in part by the Conselho Nacional de Desenvolvimento Científico e Tecnológico Brasil (CNPq), the Fundação de Apoio à Pesquisa e a Inovação Tecnológica do Estado de Sergipe (Fapitec/SE) - Brasil, the Coordenação de Aperfeiçoamento de Pessoal de Nível Superior Brasil (CAPES - Finance Code 001), the Financiadora de Estudos e Projetos - Brasil (FINEP), and the Universidade Federal de Sergipe, Brasil.

\section{DECLARATION OF CONFLICT OF} INTERESTS

The authors declare no conflict of interest. The founding sponsors had no role in the design of the study; in the collection, analyses, or interpretation of data; in the writing of the manuscript, and in the decision to publish the results. 


\section{AUTHORS' CONTRIBUTIONS}

All authors contributed equally to the design and writing of the manuscript. All authors critically reviewed the manuscript and approved the final version.

\section{REFERENCES}

ATTARDO, G. M. et al. Nutritional regulation of vitellogenesis in mosquitoes: Implications for anautogeny. Insect Biochemistry and Molecular Biology, v.35, n.7, p.661-675, jul. 2005. Available from: <https://doi.org/10.1016/j.ibmb.2005.02.013>. Accessed: Mar. 05, 2019.

BOTTEGA, D. B. et al. Comportamento de Podisus nigrispinus (Dallas) (Hemiptera: Pentatomidae) na interação com lagartas de Spodopteracosmioides (Walker) (Lepidoptera: noctuidae) e cultivares de soja com diferentes graus de resistência. Revista de Agricultura, v.89, n.1, p.53-64, 2014. Available from: <http://www. revistadeagricultura.org.br/index.php/revistadeagricultura/article/ view/157>. Accessed: Aug. 03, 2020. doi: 10.37856/bja.v89il.157.

BUSATO, G. R. et al. Consumo e utilização de alimento por Spodoptera frugiperda (J. E. Smith, 1797) (Lepidoptera: Noctuidae) em duas temperaturas. Ciência e Agrotecnologia, v.28, n.6, p.1278-1283, dez. 2004. Available from: <https:// doi.org/10.1590/S1413-70542004000600008>. Accessed: Mar. 21, 2019.

CARRANO-MOREIRA, A. F. Manejo Integrado de Pragas Florestais: Conceitos, fundamentos ecológicos e táticas de controle. 1 ed. Rio de Janeiro: Technical Books, 2014. 349p.

CHAPMAN R. F. The insects: Structure and function. 5 ed. Cambridge: United Kingdom, 2013.

COSTA, V. H. D. da et al. Egg storage of Podisus nigrispinus (Hemiptera: Pentatomidae) Predators at low temperatures. Revista Árvore, v.40, n.5, p.877-884, out. 2016. Available from: $<$ https://doi.org/10.1590/0100-67622016000500011>. Accessed: Out. 10, 2018.

DAVIDOWITZ, G. et al. Critical weight in the development of insect body size. Evolution \& development, v.5, n.2, p.188197, 2003. Available from: <https://doi.org/10.1046/j.1525142X.2003.03026.x>. Accessed: Jan. 21, 2019.

FERREIRA, D. F. Sisvar: a Guide for its Bootstrap procedures in multiple comparisons. Ciência e Agrotecnologia, v.38, n.2, p.109-112, 2014. Available from: <https://doi.org/10.1590/S14137054201400020000>. Accessed: Aug. 21, 2018.

FERREIRA, J. A. M. et al. Predatory behaviour of Podisus nigrispinus (Heteroptera: Pentatomidae) on different densities of Anticarsia gemmatalis (Lepidoptera: Noctuidae) larvae. Biocontrol Science and Technology, v.18, n.7, p.711-719, set. 2008. Available from: < https://doi.org/10.1080/09583150802271220>. Accessed: Mar. 20, 2019.

HADDAD, M. L. et al. Métodos para estimar os limites térmicos inferior e superior de desenvolvimento de insetos. Piracicaba: Fundação de Estudos Agrários Luiz de Queiroz, 1999. 29p.

LEMOS, W. DE P. et al. Effects of diet on development of Podisus nigrispinus (Dallas)(Het., Pentatomidae), a predator of the cotton leafworm. Journal of Applied Entomology, v.127, n.389-395, 2003. Available from: $<$ https://doi.org/10.1046 /j.1439-0418.2003.00765.x>. Accessed: Jan. 10, 2019.

LEMOS, W. DE P. et al. Morphology of female reproductive tract of the predator Podisus nigrispinus (Dallas) (Heteroptera: Pentatomidae) fed on different diets. Brazilian Archives of Biology and Technology, v.48, n.1, p.129-138, jan. 2005a. Available from: $<$ https://doi.org/10.1046/j.1439-0418.2003.00765. $\mathrm{x}>$. Accessed: Jan. 10, 2019.

LEMOS, W. P. et al. Effect of diet on male reproductive tract of Podisus nigrispinus (Dallas) (Heteroptera: Pentatomidae). Brazilian Journal of Biology, v.65, n. 1, p.91-96, 2005.b. Available from: $\quad<$ https://doi.org/101590/S1519-69842005000100012>. Accessed: Dec. 13, 2017.

LUNDGREN, J. G. Reproductive ecology of predaceous Heteroptera. Biological Control, v.59, n.1, p.37-52, out. 2011. Available from: <https://doi.org/10.1016/j. biocontrol.2011.02.009>. Accessed: Sep. 18, 2018.

MEDEIROS, R. S. et al. Age-dependent fecundity and life-fertility tables for Podisus nigrispinus (Dallas) (Het., Pentatomidae). Journal of Applied Entomology, v.124, p.319-324, 2000. Available from: <https://doi.org/10.1046/j.1439-0418.2000.00482. $\mathrm{x}>$. Accessed: Nov. 13, 2018.

MEDEIROS, R. S. et al. Temperature influence on the reproduction of Podisus nigrispinus, a predator of the noctuid larva Alabama argillacea. BioControl, v.48, n.6, p.695-704, 2003. Available from: <https://doi.org/10.1023/A:1026395729902>. Accessed: Sep. 21, 2018.

MEDEIROS, R. S. et al. Estimative of Podisus nigrispinus (Dallas) (Heteroptera: Pentatomidae) development time with non linear models. Neotropical Entomology, v.33, n.2, p.141148, apr. 2004. Available from: <https://doi.org/10.1590/S1519566X2004000200003>. Accessed: Mar. 31, 2020.

NEVES, R. C. et al. Production and storage of mealworm beetle as prey for predatory stinkbug. Biocontrol Science and Technology, v.20, n.10, p.1013-1025, ago. 2010. Available from: <https://doi. org/10.1080/09583157.2010.500718>. Accessed: Oct. 04, 2018.

RAHMATHULLA, V. K.; SURESH, H. M. Seasonal Variation in Food Consumption, Assimilation, and Conversion Efficiency of Indian Bivoltine Hybrid Silkworm, Bombyx mori. Journal of Insect Science, v.12, n.82, p.1-14, jul. 2012. Available from: <https://doi.org/10.1673/031.012.8201>. Accessed: Feb. 19, 2019.

REBAUDO, F.; RABHI, V. B. Modeling temperature-dependent development rate and phenology in insects: review of major developments, challenges, and future directions. Entomologia Experimentalis et Applicata, v.166, n.8, p.607-617, ago. 2018. Available from: <https://doi.org/10.1111/eea.12693>. Accessed: Oct. 08,2018

SANTOS, Í. T. B. F. DOS et al. Effects of temperature on the development of Podisus nigrispinus (Heteroptera: Pentatomidae): Implications for Mass Rearing. Florida Entomologist, v.101, n.3, p.458-463, set. 2018. Available from: <https://doi. org/10.1653/024.101.0303>. Accessed: Oct. 01, 2018.

SILVA, C. A. D. Effects of temperature on the development, fecundity, and longevity of Gargaphia torresi Lima (Hemiptera, 
Tingidae). Revista Brasileira de Entomologia, v.48, n.4, p.547552, dec. 2004. Available from: <https://doi.org/10.1590/S008556262004000400018>. Accessed: Mar. 31, 2020.

SOARES, M. A. et al. Ovary development, egg production and oviposition for mated and virgin females of the predator Podisus nigrispinus (Heteroptera: Pentatomidae). Acta Science, v.33, n.4, p.597-602, 2011. Available from: <https://doi.org/10.4025/ actasciagron.v33i4.6694>. Accessed: Mar. 27, 2020.

TORRES, J. B. et al. Dispersal of Podisus nigrispinus (Heteroptera: Pentatomidae) nymphs preying on tomato leafminer: Effect of predator release time, density and satiation level. Journal of Applied Entomology, v.126, p.326-332, 2002. Available from: $<$ https://doi.or g/10.1046/j.1439-0418.2002.00653.x>. Accessed: Mar. 23, 2019.

TORRES, J. B. et al. The predatory stinkbug Podisus nigrispinus: biology, ecology and augmentative releases for lepidoperan larval control in Eucalyptus forests in Brazil. CAB Reviews: Perspectives in Agriculture, Veterinary Science, Nutrition and Natural Resources, v.1, n.015, p.1-18, 1 abr. 2006. Available from: $<$ https://www.cabi.org/bni/FullTextPDF/2006/20063071083.pdf> Accessed: Mar. 23, 2019. doi: 10.1079/PAVSNNR20061015.

VACARI, A. M. et al. Effect of Egg Rearing Temperature and Storage Time on the Biological Characteristics of the Predatory Stink Bug Podisus nigrispinus (Hemiptera: Pentatomidae). Annals of the Entomological Society of America, v.107, n.1, p.178-183, 1 jan. 2014. Available from: $<$ https://doi.org/10.1603/AN13027>. Accessed: Sep. 16, 2018.
VACARI, A. M. et al. Desenvolvimento de Podisus nigrispinus (Dallas, 1851) (Hemiptera: Pentatomidae) alimentado com lagartas de Diatraea saccharalis (Fabricius, 1794) (Lepidoptera: Crambidae). Arquivo do Instituto Biológico, v.74, n.3, p.259-265, 2007. Available from: <http://www. biologico.agricultura.sp.gov.br/uploads/docs/arq/v74_3/vacari. pdf>. Accessed: Aug. 03, 2020.

WANG, X.-G. et al. Larger olive fruit size reduces the efficiency of Psyttalia concolor, as a parasitoid of the olive fruit fly. Biological Control, v.49, n.1, p.45-51, abr. 2009. Available from: $<$ https://doi.org/10.1016/j.biocontrol.2009.01.004>. Accessed: Jan. 16, 2019.

ZANUNCIO, J. et al. Hemipterous predators of eucalypt defoliator caterpillars. Forest Ecology and Management, v.65, n.1, p.65-73, 1994. Available from: <https://doi.org/10.1016/03781127(94)90258-5>. Accessed: Sep. 08, 2018.

ZANUNCIO, J. C. et al. Effect of body weight on fecundity and longevity of the stinkbug predator Podisus rostralis. Pesquisa Agropecuária Brasileira, v.37, n.9, p.1225-1230, 2002. Available from: <https://doi.org/10.1590/S0100-204X2002000900004>. Accessed: Sep. 11, 2018.

ZERBINO, M. S. et al. Phenological and physiological changes in Adult Piezodorus guildinii (Hemiptera: Pentatomidae) Due to Variation in Photoperiod and Temperature. Florida Entomologist, v.97, n.2, p.734-743, jun. 2014. Available from: <https://doi. org/10.1653/024.097.0255>. Accessed: Jan. 28, 2019. 